\title{
EGFR-TKI Resistant Mutation
}

National Cancer Institute

\section{Source}

National Cancer Institute. EGFR-TKI Resistant Mutation. NCI Thesaurus. Code C96862.

A molecular genetic abnormality indicating the presence of resistance in the epidermal growth factor receptor-tyrosine kinase inhibitor domain, due to secondary mutations of the EGFR gene. 